\title{
Constantin Schreiber, Inside Islam. Was in Deutschlands Moscheen gepredigt wird, współpr. Hamza Jarjanazi, Berlin 2018, ss. 253
}

G rupą religijną, która w Europie wzbudza zainteresowanie nie tylko wśród badaczy, lecz także przeciętnych mieszkańców, są muzułmanie. Do krajów z niemałym odsetkiem wyznawców islamu należą Niemcy. Sytuacja ta jest m.in. konsekwencją gospodarczego boomu lat 60 . i 70. XX wieku i decyzji o ściągnięciu do kraju tanich robotników (tzw. gastarbeiterów), w tym pochodzących z Turcji i (częściowo) Jugosławii muzułmanów. Jak prezentuje się ta społeczność w dzisiejszych Niemczech - w sytuacji, gdy zamieszkuje ona tam już w trzecim pokoleniu? Kwestii tej, lecz z charakterystycznego punku widzenia - bo uprawianego w meczetach kaznodziejstwa - poświęcone zostało opracowanie niemieckiego dziennikarza Constantina Schreibera (1979-), specjalisty od tematyki bliskowschodniej. Potwierdzeniem jego kompetencji są lata aktywności jako korespondenta w Libanie i Zjednoczonych Emiratach Arabskich oraz znajomość języka arabskiego (s. 10-11).

Tytuł książki Schreibera można przetłumaczyć następująco: Islam od środka. $O$ czym głosi sie kazania $w$ niemieckich me- czetach. Składają się na nią trzy zasadnicze części: Wprowadzenie (Einleitung), s. 9-42; Piatkowe kazania (Die Freitagspredigten), s. 43-232 oraz Podsumowanie (Resümee), s. 233-245. Na końcu zamieszczono także Przypisy (Anmerkungen), s. 246-253. Spośród powyższych trzech części najobfitsza jest druga. W jej ramach zaprezentowano trzynaście kazań, które zostały wygłoszone w meczetach w Berlinie, Hamburgu, Lipsku, Magdeburgu, Karlsruhe i Poczdamie. Zanim przytoczono treść analizowanego kazania, wskazywano na aktualne wydarzenia z Niemiec i ze świata oraz prezentowano wygląd meczetu i jego okolicy. Następnie autor w krytyczny sposób ustosunkowywał się do zawartego w kazaniach przesłania. Czynił to samodzielnie lub posiłkował się opiniami ekspertów. Lektura książki uzasadnia opinię, że można by zrezygnować z omawiania bieżących wydarzeń, gdyż nie odnoszono się do nich w czasie kazań. Jest to jeden z momentów, w ramach których potwierdza się motyw wyobcowania czy też paralelności muzułmanów w stosunku do tego, co niemieckie. 
Autor podkreśla, że chodziło mu o reportaż, a nie o systematyczne badanie naukowe. Wyboru odwiedzanych w okresie ośmiu miesięcy meczetów dokonał, korzystając ze wskazówek znajomych oraz informacji pozyskanych $\mathrm{w}$ internecie. Kazania były nagrywane, a następnie tłumaczone przez specjalistów. Mógłby to zrobić sam, ale z jednej strony używany arabski był miejscami dla niego zbyt skomplikowany, z drugiej zaś chciał nabrać dystansu do kazania, tj. spojrzeć na nie oczyma tłumacza. Interesujące jest to, że miał problemy ze znalezieniem tłumaczy ( $\mathrm{z}$ języka arabskiego i tureckiego) - zarzucano mu m.in., że uprawia nagonkę na islam. Sytuacja powtórzyła się, gdy szukał znawców islamu, którzy pomogliby mu w dotarciu do myślenia przeciętnego słuchacza kazania, tj. do tego, co on (najprawdopodobniej) weźmie do swojej codzienności. Sugerowano, żeby dał sobie spokój, że materia jest zbyt skomplikowana, a jego działania mogą przyczynić się do wzrostu napięć (s. 37-40, 233).

Autor akcentuje, że o tym, co dzieje się w meczetach, nie wie przeciętny Niemiec, gdyż co innego mówi się do (niemieckich) kamer, a co innego, kiedy są one wyłączone i nie ma w pobliżu niemuzułmanów (s. 44-45). Wspomina, że będąc w jednym z meczetów, znalazł broszurę wysoce krytyczną wobec Zachodu. Pytany o to imam wyjaśnił, że na pewno ktoś ją podrzucił (s. 13-14). Problem braku rzetelnej wiedzy dotyka także tych, którzy w imieniu państwa powinni takową posiadać. Nie chodzi tu o dokładne rozeznanie w meandrach islamskiego życia, lecz o proste dane, np. ile jest w Niemczech meczetów. Niewiedza wynika ze specyficznego przewrażliwienia - nie wolno nikogo szkalować, piętnować itd. Autor przywołuje tłumaczenie władz niemieckich doty- czące braku danych - nie można prowadzić spisu meczetów, gdyż byłby to negatywny sygnał, że się wszystkie meczety traktuje z podejrzliwością. $\mathrm{Na}$ tym tle ciekawostką jest to, że tego typu oporów nie ma w sytuacji, gdy zbierane są dane dotyczące społeczności protestanckiej i katolickiej (s. 33-35). Nie wiadomo także, ilu dokładnie muzułmanów przebywa w Niemczech. Wynika to znowu z osobliwej zachowawczości - w ramach przedostatniego spisu pytanie dotyczące przynależności religijnej potraktowano jako nieobowiązkowe a w czasie ostatniego w ogóle go nie zadano. Bazując na opracowaniu Życie muzutmańskie w Niemczech (Muslimisches Leben in Deutschland) z 2008 roku, spisie ludności z 2011 oraz danych Federalnego Urzędu ds. Migracji i Uchodźców (Das Bundesamt für Migration und Flüchtlinge) z 2015 roku, wylicza się, że w Niemczech zamieszkuje obecnie 4,4-4,7 $\mathrm{mln}$ muzułmanów (s. 32).

W oficjalnej narracji badani muzułmanie prezentują siebie jako część niemieckiego społeczeństwa, czego potwierdzeniem jest deklarowana akceptacja wartości przyświecających demokratycznemu państwu. Wielu polityków naiwnie przyjmuje tego typu wypowiedzi jako odbijające stan rzeczywisty. Np. kanclerz Angela Merkel wielokrotnie powtarzała, że islam jest częścią Niemiec. Autor wskazuje, że powyższe przekonanie uwidacznia się także $\mathrm{w}$ różnych opracowaniach naukowych. Konfrontując je z własnymi badaniami, wyraża się krytycznie na ich temat. Opinia, że „dla muzułmanów Niemcy to w międzyczasie ojczyzna” („für Muslime ist Deutschland inzwischen Heimat") (s. 240), jest jego zdaniem nieprawdziwa. Stwierdza, że przez wszystkie kazania przewija się opinia, iż życie na „niemiecką modłę” jest czymś, co niesie ze sobą 
niebezpieczeństwo. Dlatego muzułmanie muszą się od takiego życia świadomie i skutecznie separować, czyli konieczne jest tworzenie społeczności, które opisuje się terminami getto bądź apartheid (autor nie używa tych dwóch określeń). Dzięki separacji muzułmanie zachowają swą tożsamość, a także pamięć o ojczyźnie - nie o Niemczech, ale np. Turcji czy Egipcie. Autor się temu nie dziwi, szczególnie jeśli się weźmie pod uwagę fakt, że większość imamów pochodzi z Turcji i Bliskiego Wschodu i dlatego ma problemy z językiem niemieckim (s. 240-241).

Jako największe zagrożenie dla muzułmańskiej tożsamości postrzega się celebrę Bożego Narodzenia oraz Nowego Roku. Ten drugi nie jawi się muzułmanom jako obyczaj świecki, lecz na wskroś chrześcijański. Autor przywołuje opinię Vereny Klemm (1956-), profesor orientalistyki na Uniwersytecie w Lipsku, która zwraca uwagę, że Boże Narodzenie oceniane jest przez muzułmanów jako groźne, gdyż sprzeciwia się ich tożsamości kulturowej i religijnej (tj. monoteizmowi). Stąd postulat, aby oddzielić pod względem kulturowym muzułmanów i chrześcijan („Weihnachten gilt als gefährlich, weil es kulturell different ist. Es steht gegen die muslimische kulturelle und religiöse Identität. Muslime und Christen sollen kulturell auseinanderdividiert werden") (s. 210). Równie krytyczne jest nastawienie muzułmanów do uroczystego witania Nowego Roku. Nawet gdy ktoś sylwestra świętuje w domu prywatnym, to i tak naraża się na poważne niebezpieczeństwo. Stąd liczne fatwy przeciw Bożemu Narodzeniu i Nowemu Rokowi, których potwierdzeniem jest praktyka dnia codziennego. Lokalne społeczności, w których zamieszkuje większa ilość muzułmanów, są zmuszane do rezygnacji z obchodów bożonarodzenio- wych i noworocznych. Np. w szkołach nie ma okazjonalnych dekoracji, w tym choinki (s. 207-210). Obok choinki symbolem, na który muzułmanie reagują newralgicznie, jest krzyż. Autor wspomina, że był ganiony, iż akceptując znak krzyża, uczestniczy w kulcie narzędzia śmierci (s. 13).

Meczety w Niemczech można podzielić zasadniczo na dwie grupy - tureckie i arabskie. Pierwsze są bardziej zamożne, czego potwierdzeniem jest ich bogactwo architektoniczne. Wynika to z faktu, że Turcy żyją w Niemczech już w trzecim pokoleniu i że wspierani są przez Turcję. To stamtąd przysyłani są opłacani przez państwo imamowie. Meczety tureckie są zorganizowane (w przeważającej mierze) w ramach Turecko-Islamskiej Unii ds. Placówek Religijnych (DITIB), która podlega pod Urząd ds. Religijnych z siedzibą w Ankarze (Diyanet). Ten ostatni zatrudnia ponad 80 tys. osób, w tym 60 tys. imamów. Diyanet odpowiada za ok. 80 tys. meczetów w Turcji oraz 1,8 tys. poza granicami kraju. Oprócz delegowania imamów do pracy za granicą Diyanet regularnie przysyła wytyczne dotyczące pracy duszpasterskiej, w tym tematyki piątkowych kazań (s. 21-23). Arabskie meczety są wspierane przez Arabię Saudyjską, a konkretnie przez powstałą w 1962 roku Światową Ligę Islamską, która ma siedzibę w stolicy tego kraju. Warte odnotowania jest to, że władze niemieckie - i federalne, i regionalne nie sprawdzają, kto finansuje meczety oraz jak wysokie jest to wsparcie (s. 58).

Państwowe umocowanie meczetów tureckich wpływa na fakt, że głoszone tam kazania są upolitycznione - stanowią one powielenie obowiązującej w kraju linii politycznej. Inaczej prezentuje się to w meczetach arabskich - wątek polityczny jest mniej intensywnie obecny (s. 21, 241). Autor się do tego nie odnosi, ale nie wolno za- 
pominać, że islam turecki stoi pod wyraźnym wpływem tego, co narodowe, można powiedzieć, że pełni on służebną rolę wobec tureckiego narodu. W islamie arabskim motyw narodu jest drugorzędny, a nierzadko postrzega się go jako zagrożenie dla islamu, który jest powołany do ogarnięcia swymi wpływami całego świata.

Liturgia w tureckich i arabskich meczetach jest podobna, stąd praktykuje się interkomunię - akceptuje się uczestniczenie w piątkowych nabożeństwach w różnych meczetach. Uwidacznia się przy tej okazji problem natury językowej. Turcy nie znają arabskiego, a posługujący się tym drugim językiem - tureckiego. W czasie nabożeństw tureckich można dostrzec znudzenie, szczególnie gdy wygłaszający kazanie imam przywołuje cytaty w języku arabskim. Stąd nie brakuje mężczyzn, którzy urozmaicają sobie czas zabawą telefonami komórkowymi. Tureccy „parafianie” pozwalają sobie na zachowanie, które może razić arabskich muzułmanów - buczą, gdy imam przeciąga kazanie. Wynika to z faktu, że tureckie nabożeństwa nie przekraczają 40 minut, podczas gdy arabskie są znacznie dłuższe. Stąd dźwiękowy wyraz niezadowolenia, kiedy pojawia się perspektywa dłuższego nabożeństwa. Do tego nawiązują imamowie - nie tylko krytykują absencję na piątkowych nabożeństwach, lecz także pospieszne opuszczanie przez wiernych domów modlitwy (s. 146-147, 207).

W arabskich meczetach praktykowana jest modlitwa powszechna (Bittgebet), w ramach której wierni wygłaszają różnego rodzaju prośby, np. „Niech Bóg zniszczy Izrael”, „Niech Bóg wspiera nas w walce z chrześcijanami i Żydami” czy „szyici to niewierni” („Gott möge Israel vernichten”; „Gott möge uns im Kampf gegen Christen und Juden unterstützen”, „die Schiiten sind Ungläubige") (s. 21).
Tematyka podejmowana w czasie kazań jawi się jako geograficznie, a przede wszystkim mentalnie odległa w stosunku do niemieckiej rzeczywistości. Przy okazji omawiania jednego z kazań, autor stwierdza z nutą ironii, że bez problemu mogłoby ono zostać wygłoszone w Gazie (s. 77). W kazaniach widoczny jest brak rozważań o intelektualnym charakterze. Preferuje się moralizowanie, anegdotyczność i przypowieściowość. Odbija się w nich odmienny świat, w centrum którego znajduje się wyidealizowany Bliski Wschód z jego obfitością daktyli i wielbłądów. Nie ma w nim za to nawiązania do Niemiec, które postrzega się negatywnie - jako kraj mogący słuchaczom jedynie zaszkodzić (s. 55-56). Destrukcyjne oddziaływanie Niemiec ujawnia się przede wszystkim w ramach państwowej demokracji. Można temu jednak zaradzić poprzez zjednoczenie wysiłków przeciw wrogom islamu - od chrześcijan i Żydów poczynając (s. 229). Nieodzowne jest także wprowadzenie szariatu z jego prostymi zasadami, jak np. oko za oko, zab za zab (s. 201).

Pojawiają się także bardziej praktyczne motywy. Np. w czasie jednego z kazań zachęcano - z okazji zbliżającego się Święta Ofiarowania - do zaopatrywania się za pośrednictwem meczetu $\mathrm{w}$ rytualnie zarżnięte barany. Chcąc usprawnić realizację zamówień, korzysta się z nowoczesnej technologii - informację o zaszlachtowanym zwierzęciu można otrzymać SMS-em lub e-mailem (s. 111-112). Jest to dość ciekawe, gdyż w kazaniach obecna jest z jednej strony krytyka tego, co nowoczesne, z drugiej zaś muzułmanie, w tym duchowni tej religii, chętnie z owej nowoczesności korzystają (s. 194-195).

$\mathrm{Na}$ Zachodzie „papierkiem lakmusowym” wskazującym na działającą demokrację jest pozycja kobiety. Do tego usto- 
sunkowuje się autor opracowania. Zwraca uwagę, że w islamie kobieta nie cieszy się taką samą pozycją jak mężczyzna. Ten bliskowschodni brak egalitaryzmu płci muzułmanie przenoszą do Europy Zachodniej. Muzułmańskim kobietom nic nie wolno bez zgody mężczyzn, w tym opuszczać domu czy pracować zawodowo. Dla nich w meczetach są przygotowane oddzielne, gorzej wyposażone pomieszczenia. W opracowaniu odniesiono się także krótko do problemu nekrofilii, która jest tolerowana w islamie (s. 9, 184).

W Podsumowaniu autor wspomina obraz nt. islamu w Niemczech, który miał przed rozpoczęciem dziennikarskich poszukiwań, a który zweryfikował po ich zakończeniu. Nie jest tak, jak się chętnie wskazuje, że meczety w czasie piątkowych modlitw są zdominowane przez starszych. Większość tam obecnych to ludzie młodzi, a nawet dzieci, a więc osoby, które w ten sposób nie wywiązują się z obowiązku szkolnego. Pojawiając się w meczetach jako dziennikarz, autor obawiał się wrogiego nastawienia osób tam obecnych. Nie spotkał się z czymś takim - traktowano go normalnie. Jednocześnie w ośmiu meczetach odmówiono mu rozmowy z imamem. Nie spotkał się także z wyraźnym nawoływaniem do przemocy, jednak konfrontując ten fakt m.in. z wyraźną niechęcią do Niemiec, zwraca uwagę, że ta sytuacja do końca go nie przekonuje. Meczety to przestrzeń, która ma ważne znaczenie w odniesieniu do imigracji - z jednej strony większość znajdujących się tam osób to (nawet z krótkim stażem w Niemczech) cudzoziemcy lub ich potomkowie, z drugiej zaś to tam chętnie podejmuje się temat łączony z imigracją, tj. integrację. Nie zachę- ca się do niej, przeciwnie - podkreśla się, że muzułmanie powinni zrobić wszystko, aby się nie zintegrować z Niemcami (s. 235-244).

Opracowanie Inside Islam jest ciekawe. Są w nim jednak idee, z którymi trudno się zgodzić. Autor stale przywołuje fakt, że w meczetach nie używa się języka niemieckiego, tylko turecki lub arabski. Uważa, że wprowadzenie do meczetów niemczyzny sprawi, że modlący się tam chętniej będę integrowali się w społeczeństwie niemieckim. Raczej nie to leży u podstawy problemu. W Niemczech funkcjonuje etniczne duszpasterstwo dla chrześcijan (w tym dla polskich katolików). Jego istotnym elementem jest używanie mowy ojczystej przybyszów. Sytuacja ta nie przeszkadza im w integrowaniu się w społeczeństwie niemieckim. Autor opracowania zapomina o tym, że w stosunku do religijnej rzeczywistości, która naznaczona jest wysokim stopniem intymności, wielu pragnie czuć się swojsko (,jak w domu”) i dlatego preferuje język ojczysty. Niby to dostrzega, gdy przywołuje starszych Turków i pisze o specyficznym „szpagacie”, który robią pomiędzy krajem pochodzenia i osiedlenia (s. 184), a jednocześnie nie potrafi wyciągnąć właściwych wniosków. Krytyka upolitycznienia kazań w meczetach (szczególnie tureckich) naznaczona jest niekonsekwencją - być może nieświadomie, ale autor oczekuje ich upolitycznienia, jednak innego, bo na służbie niemieckiej racji stanu - mają one stać się niejako miejscem „niemieckiego wychowania obywatelskiego”. Rzeczywistość jest daleka od jego oczekiwań. Ale czy w wolnych Niemczech wolni muzułmanie nie mają do tego prawa? 